\title{
Effect of Grafting Dates, Methods on Success and Growth of Mandarin (Citrus reticulata Blanco) Sapling
}

\author{
B. Chalise' ${ }^{1}$ D.R. Baral'², D.M. Gautam ${ }^{2}$ and R.B. Thapa ${ }^{2}$ \\ ${ }^{1}$ Agricultural Research Station, Dailekh \\ ${ }^{2}$ Institute of Agriculture and Animal Science, Rampur, Chitwan \\ e-mail: basantchalise@gmail.com
}

\begin{abstract}
A field experiment was conducted at National Citrus Research Program (NCRP), Paripatle, Dhankuta to standardize the time and method of grafting and to assess the success and growth of mandarin saplings. Scions taken from 'Khoku Local' mandarin were grafted onto one-year-old trifoliate orange seedling rootstocks by shoot tip and veneer methods in eight different dates starting from $29^{\text {th }}$ October, 2009 to $12^{\text {th }}$ February, 2010 at 15 days interval. The grafts were planted inside closed tunnel of jute and plastic sheet at $10 \times 10 \mathrm{~cm}$ spacing in $50 \times 60 \mathrm{~cm}^{2}$ experimental plots in two factorial split-plot design with three replications per treatment, containing 30 grafts per plot. The grafting methods were allotted on main-plots and the dates on sub-plots randomly. The success and growth of sapling was significantly affected by the dates while the methods had no effect. Study results showed that the highest success $(96.11 \%)$ was found on $13^{\text {th }}$ January, followed by $28^{\text {th }}$ January $(91.11 \%)$ and the least $(51.67 \%)$ on $29^{\text {th }}$ October grafting. The mortality of sprouted grafts was the lowest $(0.17 \%)$ in $29^{\text {th }}$ December grafting, while it was observed higher in earlier and late season grafting. Observation on growth taken at 180 days after grafting in successful grafts showed that $29^{\text {th }}$ October had the highest number of primary branches $(2.2) ; 14^{\text {th }}$ November had the highest number of leaves (48.47) and secondary branches $(2.505) ; 29^{\text {th }}$ December gave the maximum sapling height $(32.86 \mathrm{~cm}) ; 13^{\text {th }}$ January produced the lowest number of leaves $(21.93)$ per sapling and $28^{\text {th }}$ January produced the lowest number of primary (1.533) and secondary branches (1.172) per sapling. From the study it was revealed that in Dhankuta, the most appropriate time of grafting was $2^{\text {nd }}$ to $4^{\text {th }}$ week of January.
\end{abstract}

Key words: citrus, propagation, callus, cambium, mortality, graft success

\section{Introduction}

Citrus is the most important fruit crop of Nepal. APP (1995) has envisaged citrus as the number one priority crop for mid-hill region. Citrus is commercially cultivated in 42 mid-hill districts (Regmi et al. 2009). Among citrus fruits, mandarin is the most important and popular fruit. It is mainly cultivated throughout the mid-hill regions of Nepal ranging the elevation from $750 \mathrm{~m}$ to $1,400 \mathrm{~m}$ above mean sea level which stretches from the East to the Far-western region (Shah 1992). Total area, production and productivity of mandarin of Nepal at present is 24,284 ha, 166,612 $\mathrm{mt}$ and $10.89 \mathrm{mt} / \mathrm{ha}$ respectively (MOAC 2012). Mandarin is the major fruit of Dhankuta which covers about 718 ha, with total production and productivity of 4,388 $\mathrm{mt}$ and $9.20 \mathrm{mt} /$ ha respectively (MOAC 2012).

The productivity of citrus fruit in Nepal is still very low. Several factors are associated in reduced yield. Citrus decline due to diseases and poor nutrient management is a serious problem in Nepal (Baral 2008). Phytophthora root rot, huanglongbing (HLB), citrus tristeza virus (CTV), powdery mildew, citrus blight, gummosis etc. are the major diseases of citrus associated with citrus decline in Nepal. Regmi et al. (2009) reported seedling trees are highly susceptible to Phytophthora root rot disease which is one of the devastating diseases of citrus. Therefore, grafting onto 
trifoliate orange rootstock could be the solution of the citrus decline malady as it is tolerant to Phytophthora root rot, resistant to the citrus tristeza virus, less susceptible to blight and extremely suitable for the heavier soil conditions of the country.

The demand of citrus saplings is rising annually. Government of Nepal has put the target to increase citrus areas up to 35,000 ha by 2015 . Thus, the area under citrus is to be increased with a rate of more than 1,000 ha per year (Regmi \& Shrestha 2001). The annual requirement of citrus saplings is estimated as 300,000 in Nepal. To meet the escalating demand of the saplings, nursery persons should adopt suitable method of grafting at right time.

Success of grafting is highly influenced by the several factors like temperature, relative humidity, moisture and plant water, growth stage of scion and rootstock, air, method of grafting, genetic relationship between the stock and the scion etc. (Hartmann et al. 2007). Few studies conducted in citrus in western and mid-western regions of Nepal revealed that winter season is the best time for grafting. In Dhankuta, Paudyal (1999) observed that November is suitable for grafting. Poon (1999) reported in mandarin that $83.75 \%$ success with tongue grafting, $85.80 \%$ with saddle grafting, $88.73 \%$ with shoot tip, $90.35 \%$ with cleft and $91.75 \%$ with veneer method. For mandarin sapling production, Gautam et al. (2001) suggested that grafting from $16^{\text {th }}$ to $31^{\text {st }}$ January was the best time for Lumle condition, who observed the maximum success $(87.50 \%)$ on $31^{\text {st }}$ January grafting. Similarly, Adhikari (2006) reported the highest graft success $(79.73 \%)$ in acid lime on $16^{\text {th }}$ January by shoot tip method.

Several studies were conducted in the past on citrus propagation at different time with different methods of grafting at different agro-ecological regions of Nepal. However, in Dhankuta, study was limited in pummelo, which is mainly cultivated in Terai regions. Studies and documentation was lacking at Dhankuta in mandarin. In this context, this study was undertaken to standardize the time and method of grafting and assess the subsequent growth of mandarin saplings.

\section{Methodology}

The experiment was conducted at National Citrus Research Program, Paripatle, Dhankuta in winter season. Scions from the mother plant of 'Khoku Local' mandarin were grafted onto one-year-old trifoliate orange seedling rootstocks by shoot tip and veneer methods on eight different dates starting from $29^{\text {th }}$ October, 2009 to $12^{\text {th }}$ February, 2010 at 15 days intervals. The grafts were planted inside the closed tunnel made from bamboo splits, jute and plastic sheet at $10 \times 10 \mathrm{~cm}$ spacing in $50 \times 60 \mathrm{~cm}^{2}$ experimental plots in two factorial split-plot design. Treatments were replicated three times. There were a total of 48 experimental plots. Thirty grafts were planted in each experimental plot. The methods of grafting were allotted on the main plots and the dates on the sub-plots randomly. The beds were prepared by digging with spade three times. At final digging, vermi-compost (Nitrogen 1.25-2.50\%, Phosphorus $0.75-1.60 \%$ and Potash $0.50-1.10 \%$ ) was mixed thoroughly with soil. Each experimental plot received $5 \mathrm{~kg}$ vermi-compost $(4 \mathrm{~kg}$ per plot at final bed preparation and $1 \mathrm{~kg}$ per plot at top dressing, 4 months after grafting). The tunnel was made by bamboo splits and jute sheet cover from inside and the plastic cover from outside. The height of tunnel at centre was $50 \mathrm{~cm}$ from the level of bed. Bamboo splits were used for construction of tunnel by bending and fixing them in a semi-circle shape in the ground. Irrigation, desuckering, weeding, hoeing and topdressing, plant protection, opening and closing of tunnel, removal of plastic laces were done as intercultural operations. First data were taken at 15 days after grafting and continued at every 15 days intervals. Statistical analysis was done by MSTAT-C package and mean separation by DMRT. Graft success and mortality was calculated with the following formulae:

\section{Graft success}

Grafts having sprouted scion were recorded in successful graft whereas unsprouted and dead scions were considered as failure ones. In some grafts late sprouting was also observed and finally, sprouting percentage was considered as the graft success.

$$
\text { Graft success }(\%)=\frac{\text { Number of sprouted graft }}{\text { Total number of grafts }} \times 100
$$

\section{Mortality}

All the sprouted scions do not produce successful grafts. Death of sprouted grafts was observed during the study which was recorded in mortality percentage. Mortality percentage was calculated with the following formula: 
Mortality $(\%)=\underline{\text { Number of dead grafts after sprouting } \times 100}$ Total number of sprouted grafts

\section{Results and Discussion}

\section{Graft success}

The effect of methods of grafting was observed non significant from initial to final observation. However, the maximum success $(82.08 \%)$ was given by veneer method as compared to shot tip method (77.78\%). The effect of dates on success and growth of mandarin was found highly significant. At final observation, success percentage is varied from $51.67 \%$ to $96.11 \%$. The highest graft success $(96.11 \%)$ was recorded in sapling prepared on $13^{\text {th }}$ January. Grafting on $28^{\text {th }}$ January gave $91.11 \%$ graft success which was statistically at par with $13^{\text {th }}$ January grafting (Table 1 ).

Table1. Effect of dates of grafting on graft success of mandarin in Paripatle, Dhankuta, 2009/2010

\begin{tabular}{|c|c|c|c|c|c|}
\hline Dates of grafting & \multicolumn{5}{|c|}{ Sprouted scion (\%) } \\
\hline & $15 \mathrm{DAG}$ & $30 \mathrm{DAG}$ & $45 \mathrm{DAG}$ & $60 \mathrm{DAG}$ & $180 \mathrm{DAG}$ \\
\hline $29^{\text {th }}$ October & $21.11^{\mathrm{a}}$ & $42.22^{\mathrm{a}}$ & $51.11^{\mathrm{c}}$ & $51.67^{\mathrm{d}}$ & $51.67^{\mathrm{f}}$ \\
\hline $14^{\text {th }}$ November & $11.67^{\mathrm{b}}$ & $34.44^{\mathrm{bc}}$ & $67.78^{\mathrm{b}}$ & $71.11^{\mathrm{c}}$ & $72.22^{\mathrm{e}}$ \\
\hline $29^{\text {th }}$ November & $5.00^{\mathrm{c}}$ & $28.89^{\mathrm{cd}}$ & $66.11^{\mathrm{b}}$ & $72.22^{\mathrm{c}}$ & $73.33^{\mathrm{e}}$ \\
\hline $14^{\text {th }}$ December & $3.33^{\mathrm{c}}$ & $26.67^{\mathrm{de}}$ & $68.33^{\mathrm{b}}$ & $76.11^{\mathrm{bc}}$ & $81.67^{\mathrm{d}}$ \\
\hline $29^{\text {th }}$ December & $3.33^{\mathrm{c}}$ & $22.78^{\mathrm{de}}$ & $78.33^{\mathrm{a}}$ & $84.44^{\mathrm{a}}$ & $88.89^{\mathrm{bc}}$ \\
\hline $13^{\text {th }}$ January & $5.00^{\mathrm{c}}$ & $21.67^{\mathrm{e}}$ & $77.22^{\mathrm{a}}$ & $86.67^{\mathrm{a}}$ & $96.11^{\mathrm{a}}$ \\
\hline $28^{\text {th }}$ January & $6.67^{\mathrm{c}}$ & $26.67^{\mathrm{de}}$ & $75.00^{\mathrm{ab}}$ & $86.11^{\mathrm{a}}$ & $91.11^{\mathrm{ab}}$ \\
\hline $12^{\text {th }}$ February & $15.00^{\mathrm{b}}$ & $40.56^{\mathrm{ab}}$ & $71.11^{\mathrm{ab}}$ & $80.00^{\mathrm{ab}}$ & $84.44^{\mathrm{cd}}$ \\
\hline Mean & 8.88875 & 30.4875 & 69.37375 & 76.04125 & 79.93 \\
\hline $\mathrm{CV}(\%)$ & 37.50 & 17.22 & 9.96 & 6.99 & 6.36 \\
\hline F value & $22.48 * *$ & $13.18 * *$ & $9.41 * *$ & $28.34 * *$ & $46.19 * *$ \\
\hline $\mathrm{CD}(\mathrm{P} \leq 0.05)$ & 3.94 & 6.21 & 8.17 & 6.28 & 6.01 \\
\hline $\mathrm{SEm} \pm$ & 1.36 & 2.14 & 2.82 & 2.17 & 2.07 \\
\hline
\end{tabular}

$\mathrm{SEm} \pm=$ Standard error of mean difference, $\mathrm{CV}=$ Coefficient of variation, $\mathrm{CD}(\mathrm{Pd}$ "0.05) $=$ Critical difference at probability value 0.05 , Treatment means followed by common letter(s) within a column are not significantly different at $5 \%$ by DMRT, $\mathrm{DAG}=$ Days after grafting

The maximum success of grafting $(96.11 \%)$ was recorded on $13^{\text {th }}$ January in Paripatle, Dhankuta at $25.69^{\circ} \mathrm{C}$ average tunnel temperature and $90 \pm 5 \%$ relative humidity. At the same time, average air temperature and relative humidity was recorded as $12.52^{\circ} \mathrm{C}$ and $63.07 \%$ respectively. The temperature and relative humidity inside the tunnel was observed about 2-times and 1.5-times higher respectively as compared to air temperature and relative humidity uxhich wase achieved by closing all the edges of plastic sheet immediately after the irrigation of grafts and soaking of jute sheet. Due to the effect of temperature on callus activity, the percentage of success of grafting was observed minimum $(51.67 \%)$ on $29^{\text {th }}$ October at $36.76^{\circ} \mathrm{C}$ of average tunnel temperature, then started rising up to the $13^{\text {th }}$ January $(96.11 \%)$ at $25.69^{\circ} \mathrm{C}$ and declining started from $28^{\text {th }}$ January $(91.11 \%)$ at $27.60^{\circ} \mathrm{C}$ and onwards (Figure 1).

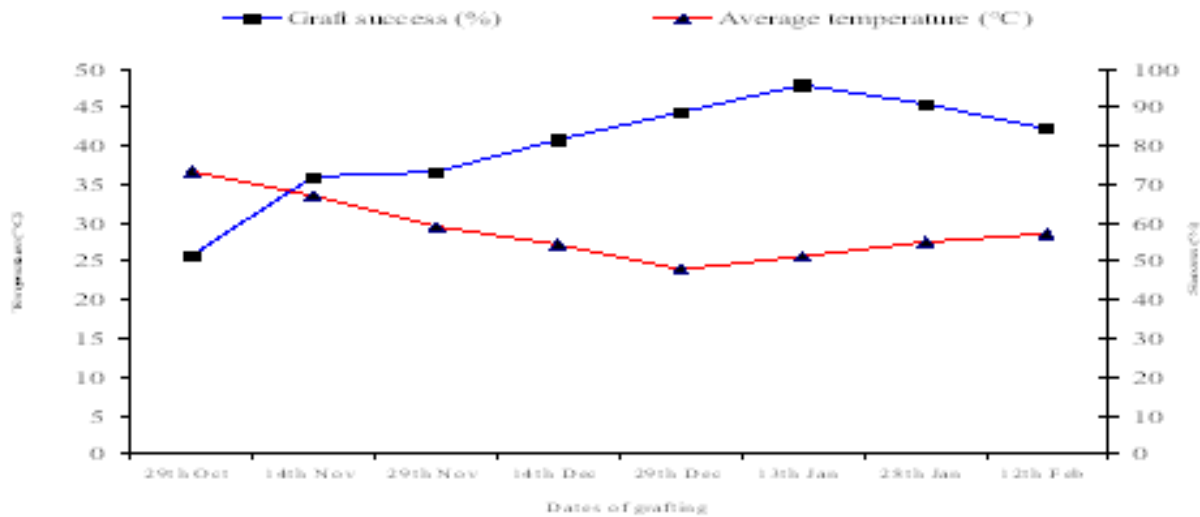

Fig.1. Relation of average tunnel temperature with graft success in different dates of grafting in Paripatle, Dhankuta, 2009/2010 
Nepal Journal of Science and Technology Vol. 14, No.1 (2013) 23-30

Present finding was also supported by Poon (1999). He reported $88.73 \%$ success with shoot tip and $91.75 \%$ success with veneer method in mandarin at Dailekh. Gautam et al. (2001) reported that $31^{\text {st }}$ January grafting gave the highest $(87.50 \%)$ and $16^{\text {th }}$ January produced $85.00 \%$ graft success in mandarin at Lumle, Kaski. Similarly, Adhikari (2006) reported highest graft success $(79.73 \%)$ in acid lime grafted onto trifoliate orange rootstock on $16^{\text {th }}$ January by shoot tip method at Rampur, Chitwan. Present result was better in comparison to the past researches in citrus. This may be due to more favorable environmental condition of Dhankuta.

\section{Mortality of sprouted grafts}

The effect of grafting methods on mortality was found statistically non significant. However, the higher percentage of mortality (1.58\%) was recorded in shoot tip method as compared to veneer method (1.12\%). The effect of dates of grafting on mortality was registered statistically highly significant. The mortality of graft as affected by dates varied from $0.17 \%$ to $3.70 \%$. The highest graft mortality $(3.70 \%)$ was recorded in the grafts prepared on $12^{\text {th }}$ February while the lowest on $29^{\text {th }}$ December (Table 2).

Table2. Effect of dates of grafting on mortality of sprouted grafts at $\mathbf{1 8 0}$ days after grafting in Paripatle, Dhankuta, 2009/2010

\begin{tabular}{l|c}
\hline Dates of grafting & $\begin{array}{c}\text { Mortality \% } \\
180 \mathrm{DAG}\end{array}$ \\
\hline $29^{\text {th }}$ October & $1.90^{\mathrm{b}}$ \\
$14^{\text {th }}$ November & $1.60^{\mathrm{b}}$ \\
$29^{\text {th }}$ November & $1.40^{\mathrm{b}}$ \\
$14^{\text {th }}$ December & $0.31^{\mathrm{c}}$ \\
$29^{\text {th }}$ December & $0.17^{\mathrm{c}}$ \\
$13^{\text {th }}$ January & $0.29^{\mathrm{c}}$ \\
$28^{\text {th }}$ January & $1.40^{\mathrm{b}}$ \\
$12^{\text {th }}$ February & $3.70^{\mathrm{a}}$ \\
Mean & 1.35 \\
CV\% & 42.29 \\
F value & $24.99^{* *}$ \\
CD $(\mathrm{P} \leq 0.05)$ & 0.78 \\
SEm \pm & 0.238 \\
\hline
\end{tabular}

$\mathrm{SEm} \pm=$ Standard error of mean difference, $\mathrm{CV}=$ Coefficient of variation, $\mathrm{CD}\left(\mathrm{Pd}{ }^{0} 0.05\right)=$ Critical difference at probability value 0.05 , Treatment means followed by common letter(s) within a column are not significantly different at $5 \%$ by DMRT, DAG=Days after grafting

The higher mortality of sprouted graft prepared on $12^{\text {th }}$ February was thus due to the lack of moisture needed to meet transpiration loss from the newly expanded leaves because union formation competed only at the end of March when there was higher temperature. Randhawa and Bajwa (1958) reported that normal union between the scion (Blood Red) and rootstock (Karna Khatta) was completed in about six weeks after grafting. Moreover, the transpiration loss from the tender leaves at higher temperature was high because lack of well developed cuticle layer outside the epidermis and higher number of stomata on the leaves. Thus lack of sufficient water was the principal cause of the death of early sprouted scion of the graft.

\section{Number of leaves per sapling}

The effect of methods of grafting on number of leaves per sapling was found non significant at 180 days after grafting. Shoot tip and veneer grafted saplings produced about 30 leaves per sapling (29.89 in shoot tip and 29.71 in veneer). The effect of dates of grafting on number of leaves per sapling was found highly significant at 180 days after grafting. The number of leaves per sapling was varied from 21.93 to 48.47 with mean value of 29.79. The highest number of leaves per sapling (48.47) was recorded on $14^{\text {th }}$ November grafted sapling, whereas the lowest $(21.93)$ on $13^{\text {th }}$ January grafted sapling (Table 3 ).

There was intimate contact of two graft components, the scion and the rootstock; callus cells also became fully differentiated to xylem and phloem ensuring the free movement of water and mineral nutrients to the leaf through xylem and photosynthate through phloem to the other parts of sapling. Early season grafted saplings also had well developed root system to absorb water and nutrient, the rate of photosynthesis was also higher because of easy availability of raw materials for photosynthesis. Greater the food availability, there would be more growth of whole plant. Therefore, this may be one of the reasons that October and November grafted saplings produced higher number of leaves. Present finding was also supported by Dubey and Singh (2003). They observed 47 leaves per sapling in Darjeeling mandarin grafted onto rough lemon at 11 months after grafting. Similarly, in another study, Adhikari (2006) reported the highest number of leaves per plant (47) at 135 days after grafting in acid lime in Chitwan.

\section{Sapling height}

Effect of methods of grafting on sapling height was found statistically non significant at 180 days after 


\section{B. Chalise et al./Effect of Grafting Dates and.......}

grafting. Sapling height was recorded as $31 \mathrm{~cm}$ in shoot tip grafted sapling and $31.88 \mathrm{~cm}$ in veneer grafted sapling. However, the effect of dates was found significant at 180 days after grafting. The height of sapling varied from $29.03 \mathrm{~cm}$ to $32.86 \mathrm{~cm}$ with mean value $31.44 \mathrm{~cm}$. Maximum height of sapling was registered on $29^{\text {th }}$ December and the minimum on $29^{\text {th }}$ October. Except $29^{\text {th }}$ October grafted sapling, rest dates were statistically at par (Table 3 ).

Table 3. Effect of dates of grafting on growth of different parameters of mandarin sapling at 180 days after grafting in Paripatle, Dhankuta, 2009/2010

\begin{tabular}{|c|c|c|c|c|}
\hline \multirow[t]{2}{*}{ Dates of grafting } & \multicolumn{4}{|c|}{ Sapling growth } \\
\hline & $\begin{array}{l}\text { Number of } \\
\text { leaves/sapling }\end{array}$ & $\begin{array}{l}\text { Sapling height } \\
(\mathrm{cm})\end{array}$ & $\begin{array}{c}\text { Number of primary } \\
\text { branches/sapling }\end{array}$ & $\begin{array}{l}\text { Number of secondary } \\
\text { branches/sapling }\end{array}$ \\
\hline $29^{\text {th }}$ October & $34.38^{\mathrm{b}}$ & $29.03^{\mathrm{b}}$ & $2.20^{\mathrm{a}}$ & $2.34^{\mathrm{ab}}$ \\
\hline $14^{\text {th }}$ November & $48.47^{\mathrm{a}}$ & $31.91^{\mathrm{a}}$ & $2.15^{\mathrm{ab}}$ & $2.50^{\mathrm{a}}$ \\
\hline $29^{\text {th }}$ November & $33.23^{\mathrm{b}}$ & $31.97^{\mathrm{a}}$ & $2.02^{\mathrm{ab}}$ & $2.15^{\mathrm{ab}}$ \\
\hline $14^{\text {th }}$ December & $24.73^{c}$ & $30.39^{\mathrm{ab}}$ & $1.88^{\mathrm{ab}}$ & $1.81^{\text {bcd }}$ \\
\hline $29^{\text {th }}$ December & $26.93^{b c}$ & $32.86^{\mathrm{a}}$ & $1.80^{\mathrm{bc}}$ & $2.03^{\mathrm{abc}}$ \\
\hline $13^{\text {th }}$ January & $21.93^{c}$ & $30.43^{\mathrm{ab}}$ & $1.87^{\mathrm{abc}}$ & $1.33^{\mathrm{de}}$ \\
\hline $28^{\text {th }}$ January & $24.19^{c}$ & $32.74^{\mathrm{a}}$ & $1.53^{\mathrm{c}}$ & $1.17^{\mathrm{e}}$ \\
\hline $12^{\text {th }}$ February & $24.53^{\mathrm{c}}$ & $32.17^{\mathrm{a}}$ & $1.92^{\mathrm{ab}}$ & $1.44^{\text {cde }}$ \\
\hline Mean & 29.79 & 31.44 & 1.92 & 1.85 \\
\hline CV (\%) & 20.31 & 6.79 & 14.08 & 26.15 \\
\hline F value & $12.55 * *$ & $2.38 *$ & $3.61 * *$ & $6.19 * *$ \\
\hline $\mathrm{CD}(\mathrm{P} \leq 0.05)$ & 7.16 & 2.53 & 0.32 & 0.57 \\
\hline $\mathrm{SEm} \pm$ & 2.47 & 0.87 & 0.11 & 0.19 \\
\hline
\end{tabular}

$\mathrm{SEm} \pm=$ Standard error of mean difference, $\mathrm{CV}=$ Coefficient of variation, $\mathrm{CD}(\mathrm{Pd}$ "0.05) $=$ Critical difference at probability value 0.05 , Treatment means followed by common letter(s) within a column are not significantly different at $5 \%$ by DMRT

Higher number of leaves per sapling produced more photosynthate and plant growth regulators, especially auxins, cytokinins and gibberellins, resulting faster growth of shoot as well as root. Auxins have apical dominance property of main shoot over the side branches resulting into increased sapling height. The increased number of primary and secondary branches also produced the higher number of leaves which ultimately resulted the increased sapling height (Hartmann et al. 2007). Present finding was also supported by several researchers. Paudyal (1999) found somewhat similar height of pummele grafted onto the trifoliate orange rootstock in November. Gautam et al. (2001) reported the highest sapling height grafted on $20^{\text {th }}$ November and $7^{\text {th }}$ December and lowest on $3^{\text {rd }}$ March grafting. In another study, Dubey and Singh (2003) reported that 11 months after grafting, Darjeeling mandarin grafted onto rough lemon rootstock produced $29.53 \mathrm{~cm}$ scion height. Similarly, the scion height of $21.23 \mathrm{~cm}$ was reported by Adhikari (2006) in acid lime grafted onto trifoliate orange rootstock at 4 months after grafting. In present study, 6 months after grafting, mandarin onto trifoliate orange rootstock produced much lower scion height (17.86 $\mathrm{cm}$ ) this was may be due to the use of dwarfing rootstock and difference in species taken under study and difference in climatic condition of the research sites.

\section{Number of primary branches}

Effect of methods of grafting on number of primary branches per sapling was non significant. Sapling propagated with shoot tip and veneer grafted sapling produced 1.95 and 1.89 primary branches per sapling. The effect of dates of grafting on number of primary branches per sapling was found statistically highly significant at 180 days after grafting. Sapling prepared on $29^{\text {th }}$ October produced the highest number of primary branches $(2.20)$ and $28^{\text {th }}$ January produced the minimum (1.53) branches per sapling (Table 3).

Highly significant positive correlation was observed between the number of primary branches per sapling and the number of leaves (0.62), sapling height (0.57) and the number of secondary branches per sapling (0.61) (Table 4). The ultimate growth of sapling was dependent primarily on the number of leaves per sapling which was affected by the number of primary and secondary branches on the plant. Adhikari (2006) 
reported highest number of primary branches (3.11) per sapling in acid lime grafted on $16^{\text {th }}$ January at 135 days after grafting in Chitwan, which was higher than the present results. This may be due to the difference in species taken under the study and climatic condition of the research sites.

Table 4. Coefficient of correlation (r) between different parameters of mandarin sapling in Paripatle, Dhankuta, 2009/2010

\begin{tabular}{c|c|c|c|c}
\hline & $\begin{array}{c}\text { Number of } \\
\text { leaf/sapling }\end{array}$ & $\begin{array}{c}\text { sapling height } \\
(\mathrm{cm})\end{array}$ & $\begin{array}{c}\text { Number of primary } \\
\text { branches/sapling }\end{array}$ & $\begin{array}{c}\text { Number of secondary } \\
\text { branches/sapling }\end{array}$ \\
\hline $\begin{array}{c}\text { Number of } \\
\text { leaves/sapling } \\
\text { sapling height } \\
(\mathrm{cm})\end{array}$ & 1.00 & $0.86^{* *}$ & $0.62^{* *}$ & $0.84^{* *}$ \\
$\begin{array}{c}\text { Number of primary } \\
\text { branches/sapling } \\
\begin{array}{c}\text { Number of } \\
\text { secondary } \\
\text { branches/sapling }\end{array}\end{array}$ & 1.00 & $0.57^{* *}$ & $0.69^{* *}$ \\
\hline
\end{tabular}

** Correlation is highly significant at the 0.01 level (2-tailed)

\section{Number of secondary branches}

Effect of methods of grafting on number of secondary branches per sapling was found non significant. Veneer and shoot tip grafted sapling produced 1.90 and 1.79 secondary branches per sapling respectively. However, the effect of dates of grafting was observed highly significant on number of secondary branches per sapling. The highest number of secondary branches (2.50) was recorded on $14^{\text {th }}$ November grafted sapling while the lowest number of branches $(1.17)$ on $28^{\text {th }}$ January grafted sapling (Table 3 ).

Highly significant positive correlation was found between the number of secondary branches and the number of leaves (0.84), sapling height (0.79) and the number of primary branches $(0.61)$ (Table 4$)$. Higher number of leaves per sapling accumulated more photosynthate and phytohormone which contributed for higher growth of sapling. Greater sapling height, more number of primary branches gave the higher number of secondary branch per sapling in mandarin. The number of secondary branches per sapling in present study was much lesser than reported by Adhikari (2006). He observed 5.20 secondary branches per sapling on $31^{\text {st }}$ January grafted sapling of acid lime in Chitwan. This may be due to the difference in species taken under the study and climatic condition of the research sites.

The present study showed that mandarin fruits can be propagated successfully through grafting. Either shoot tip or veneer method can best be used with higher rate of success, because shoot tip and veneer method did not differ significantly in their effect on success and growth of sapling. The most appropriate time of grafting at Dhankuta is identified as $2^{\text {nd }}$ week of January to the end of January.

\section{Acknowledgements}

The authors are thankful to Mr. Deokant Chaudhary, Coordinator, National Citrus Research Program, Paripatle, Dhankuta for providing land, equipment, scions and seedling rootstocks, manpower and other essential materials during the study. Authors also like to express sincere thanks to Prof. Dr. Sundar Man Shrestha, Dean and Prof. Dr. Shanta Man Shakya, Assistant Dean (Examination) for overall supervision, criticisms and suggestions.

\section{References}

Adhikari, A. 2006. Effect of grafting season on success and growth of acid lime (Citrus aurantifolia Swingle) in Rampur, Chitwan. M.Sc. thesis. Tribhuvan University, IAAS, Rampur, Chitwan, Nepal. 99 pp.

APP. 1995. Nepal agriculture perspective plan, final report. Agricultural Projects Services Center, Kathmandu, Nepal and John Mellor Associates, Inc., Washington DC, USA.

Baral, D. R. 2008. Performance of mandarin trees (Citrus reticulata Blanco) at different altitudes and nutrient management in mid-hills of Nepal. Ph.D. thesis. Tribhuvan University, IAAS, Rampur, Chitwan, Nepal. 244 pp.

Dubey, A. K. and A. K. Singh. 2003. Evaluation of rootstocks of different mandarins (Citrus reticulata) under foot-hills conditions of Arunachal Pradesh. 


\section{B. Chalise et al./Effect of Grafting Dates and.......}

Indian Journal of Agricultural Sciences 73(10): 527-529.

Gautam, I. P., D. N. Sah and B. Khatri. 2001. Effect of time of grafting and budding on trifoliate rootstocks for appropriate mandarin orange sapling production. Lumle Working Paper No. 2001/20. Lumle Agricultural Research Station, Lumle, Kaski, Nepal. 6 pp.

Hartmann, H. T., D. E. Kester, F. T. Davies, Jr. and R. L. Geneve. 2007. Plant propagation principles and practices. 7th ed. Prentice Hall Pvt. Ltd., New Delhi, India. $880 \mathrm{pp}$.

MOAC. 2012. Statistical information on Nepalese agriculture 2010/2011. Ministry of Agriculture and Co-operatives, Agri-Business Promotion and Statistics Division, Singha Durbar, Kathmandu, Nepal. 171 pp.

Paudyal, K. P. 1999. Genetic diversity of pummelo in Nepal and improvement of propagation methods. Ph.D. thesis. University of Southampton, UK. 174 pp.

Poon, T. B. 1999. Effect of grafting methods and time on mandarin sapling production at Dailekh. In:
Proceedings of the $2^{\text {nd }}$ National horticultural research workshop, Khumaltar, Lalitpur, May 1315, 1998. pp. 65-68.

Randhawa, S. S. and B. S. Bajwa. 1958. Histology of bud-union in citrus. Indian Journal of Horticulture $15(1): 2-5$

Regmi, C. and S. Shrestha. 2001. Study on different soil mixtures for growing Poncirus trifoliata. Environment and agriculture. In: Environment and Agriculture Biodiversity. Agriculture and Pollution in South Asia, Ecological Society, Kathmandu, Nepal. pp. 334-336.

Regmi, C., I. P. Kafle, K. P. Paudyal, R. P. Devkota, G. Aryal and G. Awasthi. 2009. Screen house system to produce quality planting materials of Citrus in Banepa. In: Proceedings of the $5^{\text {th }}$ National seminar on horticulture. Kathmandu, Nepal, June 9-10, 2008. pp. 89-92.

Shah, R. B. 1992. Trainer's manual No. 16 Citrus fruit. Manpower Development Agriculture Project, Kathmandu, Nepal. 523 pp. 
Nepal Journal of Science and Technology Vol. 14, No.1 (2013) 23-30 